\title{
CAN WE FIND THE WASHBACK EFFECTS OF INTERNATIONAL ENGLISH LANGUAGE TESTING SYSTEM ON IELTS LEARNERS?
}

\author{
Diki Riswandi \& Didik Tri Wahyudi \\ Universitas Sebelas Maret, Indonesia \\ dikiriswandi@gmail.com, mrdidiktw@gmail.com
}

\begin{abstract}
IELTS test nowadays becomes one of the most important thing to get for those especially who want to continue their study in English speaking country especially UK or Australia. Because of the important roles of this standardized tests, it effects on students' lives around the world. This study is conducted to find out the IELTS test influence on learners preparing for a test on learning and teaching outcomes and an obvious path for IELTS teachers in order to modify their methods and strategy of teaching. Therefore, the present study has tried to investigate whether IELTS preparation classes have any influence on the learning processes and the achievement of students in such an examination. To obtain the data, the writers used library research. A qualitative analysis was employed by identifying and classifying the finding of previous research of washback effects of the IELTS test toward the learners. It was found that there are positive and negative washback effects of IELTS test toward the learners.
\end{abstract}

Keywords: washback, IELTS, effects, learners.

\section{Introduction}

Having ability of sufficient English language is one of the most important thing for international students willing to study in international universities in almost all countries all around the world (Green 2007, p. 75). Some universities, before accepting international students onto their courses, will usually oblige this evidence of sufficient English language ability. There are two generally language proficiency tests which are recognized internationally i.e. IELTS and TOEFL IBT (Test of English as a Foreign Language Internet-based Test). Green (2007, p. 77) further mentioned the general different between IELTS and TOEFL that IELTS is commonly to gain access to university courses in the UK while TOEFL in the USA. However, nowadays some universities in both UK and USA accept either IELTS or TOEFL.

As the need of having a good band in IELTS is increasing, then it is highly also needed for the test-takers to know the learning strategies before facing the test. Good strategies can be obtained by prioritizing the important skills before the others. For example, those who fail in writing test should focus on improving their skills in writing and so on. Hence, it is important to analyze the washback effect of IELTS tests.

According to Hughes in Brown (2003), washback is "the effect of testing on teaching".
This might also refer to the effects of the tests have on instruction in terms of how students prepare for the test. Fulcher and Davidson (2007) comes up with the term washback as the effect that tests have on what goes on in the classroom. Washback can be for teaching as well learning. For years, washback is believed to be one of the characteristics a good test. Good tests would produce good washback and inversely that bad tests would produce bad washback.

The importance of washback leads us to find out more about the previous researches that dig up the positive and negative washback effects especially in English proficiency tests as mentioned before i.e. IELTS. Therefore, this paper attempts to review the researches related to the backwash effects of IELTS test toward IELTS learners.

\section{IELTS}

Taken from its official website, www.IELTS.org, the definition of the IELTS test is an established and widely used international English language proficiency exam made in two formats, each format has a different purpose. The two format mentioned are Academic and General Training. The test, both academic and general training, has four sections, one for each of the language skills, which are equally weighted to give an overall averaged band of proficiency measured from 
0 (lowest) to 9 (highest).

\section{Washback}

Buck (1988, p. 17) defined washback as "a natural tendency for both students and teachers to tailor the classroom activities to the demands of the test, especially when the test is particularly important for test takers". According to Bachman and Palmer (1996, p. 30) washback is a direct impact of testing on individuals. It is in line with Dorobat's statement who claimed that washback is the effect of a test has on teaching in the classroom (2007, p. 29).

The test has the power of affecting over the method and content of language courses. Thus, washback effect can be classified into two; positive and negative washback (Dorobat, 2007, p. 29). Bailey (1996, pp. 264268) put forward a basic model of washback, which identified possible participants and the direction of influence. Moreover, she further distinguished between "washback to the learners" and "washback to the program," with "the program" covering not only teachers but all the other participants apart from the students.

Positive washback occurs when it has beneficial impact on educational practices (Hughes as cited in Yi-Ching, 2009, p. 259). Another definition regarding positive washback is from Messick as cited in Cheng and Watanabe $(2008$, p. 8) who states that to avoid high positive washback, there should be difference between activities involved in learning the language and activities involved in preparing for the test. Moreover, Taylor (2005, p. 154) also states that positive washback is the result of a testing in which encourage good teaching practice; for example, an oral proficiency test is introduced in the expectation that it will promote the teaching of speaking skills. It is in line with Pearson's statement (as cited in Cheng \& Watanabe, 2004) that it will be positive if the effects are beneficial and encourage the whole range of desired changes.

Negative washback refers to the undesirable effect on teaching and learning of a particular test deemed to be poor (Alderson and Wall in Cheng and Watanabe, 2008, p.9). It means that the effect reflects to something which does not wish to happen as a result of testing in teaching and learning process. According to Pearson (as cited in Cheng \& Wata- nabe, 2004), the negative washback occurs when it fails to reflect the learning principles and course objectives to which the test supposedly relates. Some examples of negative effects of testing are: the test content and testing techniques differ from the objective of the course. Further, Taylor (2005, p. 154) states that negative washback occurs when a test's content or format is absed on narrow definition of language ability, and so contains the teaching and learning context. For example, the skill of writing is tested only by multiple choice items then there is a great pressure to practice such a items rather than to practice the skill of writing itself.

\section{Discussion \\ First article}

First discussion is talking about the journal article written by Allen (2016). This article entitles investigating washback to the learner from the IELTS test in the Japanese tertiary context. This research tried to find out the washback on learners' test preparation strategy and score gain, and the mediating factors influencing washback in the consequential validity of the IELTS exam. The methodology used by the writers was by administering two IELTS Tests to 190 undergraduates at a Japanese university over a 1-year period. to collect data about test preparation strategies for both tests, the writer used survey instrument. Test scores were compared to assess score gain. In addition, to investigate the factors mediating washback, the writer had Interviews with 19 participants.

In gaining the data, the writer used three instrument, namely, survey (questionnaire), test, and interview. Therefore, there are three kinds of data presented. First, survey data showed that test taker changed their preparation strategies for the second test, changing their focus from receptive to productive skills. Those who prepared the most focused significantly more on all skills except reading in preparation for the second test. These findings indicate that the IELTS Test generated a positive washback effect on the study of productive skills. In sum, the test data indicate positive washback on speaking skills for all participants and also on listening skills for those who prepared the most for the test. Taken together, the survey and test data suggest that studying for the IELTS Test resulted in a greater focus on productive skills, 
with evidence of an increase in proficiency in speaking, particularly at lower initial levels of proficiency. Third, interview data showed several points highlighted such as test preparation strategies, change in approaches to test preparation, perceived difficulty, perceived efficiency and effectiveness, knowledge of how to study and improve, assistance from others, and other factors.

The conclusion of this research is that it revealed the positive washback of the IELTS test. The Test gave the positive washback on learners' language ability and test preparation strategies, specifically on their productive skills. The IELTS Test in this study created a stimulus, which took students towards the study of productive skills, which is a positive step forward for the test takers' development of a rounded language proficiency, especially speaking, in the four skills. in addition, this study also found that many students tended to be more concerned on test-related task and material when they prepared for the test.

\section{Second article}

The second study was written by Rashidi and Javanmardi (2011) entitle The IELTS Preparation Washback on Learning and Teaching Outcomes. The study has tried to investigate whether IELTS preparation classes have any influence on the learning processes and the achievement of students in such an examination. This study was conducted in the Iranian context. At the same time, the purpose of this study is also to find if the construct of such tests makes any difference in the methods used in teaching. The total population of this study is sixty-four participants; fifty-five students who took part in the IELTS preparationcourse $s$ and nine IELTS teachers.

The result of this study proved that IELTS preparation courses had positive effects on the learning process of Iranian students. That is, a great thing of the course was allocated time that made students familiar with the form of the test for the strategies the students must absorb would depend on the type of questions. However, this conclusion is not totally true when the researcher reflected the students" expectation. The frequency of the students' expectations before and after taking the IELTS course displayed unrealistic results. The results presented that both before and after the courses the students felt optimistic and pessimistic on several aspects of these courses. In other words, the researchers drew another argument of the study which is no significant advantage for the students joining this programs.

\section{Complexity of Washback Effects on IELTS Learners}

Estaji and Tajeddin's (2012) research entitled Demystifying the Complexity of Washback Effect on Learners in the IELTS Academic Writing Test is aimed at exploring Whether there is any washback effect of IELTS writing tests on learners' perspectives of motivation, anxiety, test-taking strategies, and expectations of IELTS writing courses both in IELTS and non-IELTS courses. The research yields in the improvement of the students' writing scores as the washback effect of IELTS academic writing test. However, the learners' motivation to study, test-anxiety, test-taking strategies, and their expectation toward IELTS test do not change significantly.

The contribution of test preparation to learners' perspectives appeared to be minimal in this setting. Learners pursuing a testpreparation course did not obtain a significant advantage in their perspectives. However, learners intending to take the test, both the learners of IELTS Academic Writing course and the Academic Writing course, did take a significant advantage in their test performance.

Washback proved learner behaviors observed in the classroom during this study, but the degree to which they were observed varied from learner to learner. However, these behaviors were not identified as a result of student questionnaire analyses. Learner washback behavior observed in the classroom mostly included engaging in test related activities such as writing argumentative essays, or presenting the information in tables or diagrams.

It is important to reiterate that the extent to which learner perspectives reflect only test expectations was limited due to the variety of other factors influencing learner perspectives that included but were not limited to, learner motivation for study, test anxiety, test-taking strategies, and their expectations of the IELTS preparation course. Learner interviews and classroom observations revealed that learners wanted to know as much as possible about the test, and they believed it 
was the teacher's job to communicate that information to them. Learners had mixed feelings toward the exam, recognizing on the one hand that the exam made them work hard to achieve good band scores and considering on the other hand that exams were not an accurate reflection of all aspects of their study.

There may be individual differences among learners in the way they perceive and react to exams. Learner perspectives and classroom practices can be in conflict with regard to testing and washback. In this context, it seems to be washback to the program, rather than washback to the learner, which has the greater relevance to outcomes.

\section{The Relationship between the Washback Effects of IELTS Test and IELTS Candidates Life Skills}

The last review of research is the research done by Ghamarian, Motallebzadeh, and Fatemi in 2014 about the relationship between washback effect of IELTS test and IELTS candidates' life skills in Iran. The research aims to examine the washback effect of IELTS test toward Iranian students' communicative skills in daily life. The result pinpoints that there was no significant correlation between the washback effects of IELTS test and the students' communicative skills. The findings of this study show the focus of IELTS preparation courses in Iran is not on life skills oriented domains.

The research findings are in agreement with Razavipour et al. (2011) indicating high stakes test direct the teaching and learning to focus on the domains that are most likely to be seen on the test. Accordingly, the research findings show the focus of IELTS preparation courses in Iran might not be on the life skills domains since these domains might be seen as the least likely domains to appear in IELTS test.

The research findings indicate that IELTS preparation courses do not enable individuals to deal effectively with the demands and challenges they might encounter in everyday life. Therefore, the outcomes of the study indicate that the IELTS preparation courses in Iran are not designed based on life skill education curriculum. The relationship between the constructs underlying IELTS test and the Iranian IELTS candidates' communicative skill viewpoints on language proficiency is flawed due to lack of significant relationship between the two variables. The findings of the research indicate that there is a difference between the extent participants viewed their communicative skill viewpoints on language proficiency and the extent the constructs underlying IELTS test measured participants' communicative skill viewpoints on language proficiency.

\section{Conclusion}

As one of the characteristics of a good test, washback is obviously an integral part as feedback in language testing. The feedback is very important as a reference for a teacher to create qualified test. The better the quality of the washback effect is, the better quality of testing and teaching-learning process will be.

From the discussion of the four researches above, we can draw conclusion that the washback effect of IELTS test can be either positive and negative. The first research done by Allen (2016) indicates that IELTS test is beneficial for the learners' productive skill especially in speaking. They tend to focus on test-related tasks and materials when preparing for the test. The second research conducted by Rashidi and Javanmardi (2011) is in line with Allen's. IELTS candidates find learning strategies as the results of their analysis of the IELTS test they have taken before. Hence, the IELTS preparation course is advantageous for them to gain better score in the IELTS test.

Although the washback effects of IELTS test show positive effects toward the learners' achievement, Estaji and Tajjedin's research finds negative washback of IELTS test toward learners' perspectives of motivation, anxiety, test-taking strategies, and expectations of IELTS test, especially in writing skill. This study indicated that rather than being a direct automatic effect, washback is actually complex and elusive; while this study showed that there was washback from the exam onto a variety of learning areas, it also indicated that washback to the learner was not present and it varied in form and intensity. IELTS test also gave negative washback toward learners' life skills as observed by Ghamarian, Motallebzadeh, and Fatemi in 2014.

According to those reviews, the conclusion that can be drawn is that washback in IELTS test does exist. The washback can be positive or negative depending on how the teacher guides the students to take appropri- 
ate learning strategies as a result of IELTS test analysis and how learners can manage their motivation and anxiety.

\section{References}

Allen, David. (2016). Investigating washback to the learner from the IELTS test in the Japanese tertiary context. Allen Language Testing in Asia (2016) 6:7 DOI 10.1186/s40468-016-0030-z

Brown, H. Douglas. (2003). Language Assessment: Principles and Classroom Practices. San Francisco, California: Longman.

Buck, G. (1988). Testing listening comprehension in Japanese university entrance examinations. JALT Journal, 10, 12-42.

Estaji, Masoomeh. (2013). Demystifying the complexity of washback effect on learners in the IELTS academic writing test. Study in English Language Testing, Vol. 1, No.1, 2013.

Fulcher, Glenn and Davidson, Fred. (2007). Language Testing and Assessment. New York: Routledge

Green, Anthony (2007) Washback to learning outcomes: a comparative study of IELTS preparation and university presessional language courses, Assessment in Education: Principles, Policy \& Practice, $\quad 14: 1, \quad 75-97, \quad$ DOI: $10.1080 / 09695940701272880$

Ghamarian, Daniel, et al. (2014). Investigating the relationship between washback effect of IELTS test and Iranian IELTS candidates' life skills. Journal of Language and Linguistic Studies, 10(1), 137152; 2014.

Rashidi \&Javanmardi. (2012). The IELTS Preparation Washback on Learning and Teaching Outcomes. Cross-Cultural Communication Vol. 7, No. 3, 2011, pp. 132-144

DOI:10.3968/ j.ccc.1923670020110703.162

Razavipour, K., Riazi, A., \& Rashidi, N. (2011). On the interaction of test washback and teacher assessment literacy: The case of Iranian EFL secondary school teachers. English Language Teaching, 4(1), 156161. Retrieved from http:// www.ccsenet.org/journal/index.php/ elt/article/view/9677/6925 